удк 342

Н. Х. Шюкюров

\title{
ПРАВОВОЙ СТАТУС СУДЬИ КОНСТИТУЦИОННОГО СУДА
}

Постановка проблемы. Цель статьи заключается в освещении сферы обширности правового статуса судей Конституционного Суда, превращение их в наиболее эффективные и действенные фигуры социальной, политической и правовой жизни современной эпохи: подчеркивании их роли в устранении коллизий в законодательной системе, обеспечении стабильности и развития общества и государства. Проанализированы решения, принятые судьями Конституционного Суда, которые имеют особое значение в развитии правовой системы, формировании нового правосознания и реализации идей конституционализма.

Более обширная характеристика субъекта правовых отношений находит свое отражение в его правовом статусе. В юридической энциклопедии статус разъясняется как правовой статус гражданина либо как правовое положение юридического лица [1, с. 946]. О.Е. Кутафин определяет правовой статус в виде совокупности прав, свобод и обязанностей, возложенных на субъект конституционного права как субъекта правоотношений, возникающих в процессе реализации правовых норм [2, с. 163].

Анализ последних исследований и публикаций. В юридической литературе понятия «правовой статус» и «правовое положение» указываются как несущими одинаковый смысл, так и различающимися понятиями. Например, В.М. Корельский и В.Д. Перевалова считают, что «правовой статус» подобен «правовому положению». В законодательстве и правоприменительной практике они внедряются именно с этой точки зрения [3, с. 231-232]. Такие авторы, как Н.В. Витрук, В.А. Кучинский, Ю.А. Лукашева, предлагая дифференцировать эти понятия, рассматривают правовой статус как составную часть (ядро) положения субъекта права [4, с. 25-34]. По мнению А.В. Мицкевича, правовой статус - это система полномочий государственных органов и должностных лиц, признающихся конституцией и законами, а также напрямую закреплённых, правом тех или иных субъектов. По мнению автора, правовой статус субъекта права непосредственно выражает его правовую субъектность и дееспособность [5, с. 47].

Правовой статус субъекта права выражает закреплённое законодательством основное правовое положение этого субъекта.

В юридической литературе в число элементов правового статуса наряду с правами и обязанностями включаются юридическая ответственность, законные интересы, правовые гарантии, правовые нормы, определяющие статус, и т.п. С этой точки зрения в содержание правового статуса субъекта права включаются следующие его элементы:

- правосубъектность (правоспособность, дееспособность и деликтоспособность);

- основные права и обязанности, закреплённые законодательством;

- гарантии основных прав и обязанностей;

- предусмотренная законодательством ответственность за нарушение правовых обязанностей.

Хотя основы статуса судей Конституционного Суда и судов общей юрисдикции в целом и отмечаются в Конституции, конкретизация законодательством их правового статуса осуществляется принятием различных законов [7].

() Н. Х. Шюкюров, 2019 
3.А. Аскеров отмечает, что статус судей, можно сказать, одинаков. Однако существуют и некоторые отличия. Правовой статус судей Конституционного Суда регулируется Законом «О Конституционном Суде» от 23 декабря 2003 года, а статус всех других судей в основном Законом «0 судах и судьях» от 10 июня 1997 года и процессуальным законодательством. Наряду с этим единообразие статуса судей предусмотрено статьёй 92-й упомянутого Закона. Здесь указывается, что при рассмотрении дел судьи имеют один и тот же статус, права и обязанности, и различаются между собой только назначением, полномочиями и сроком полномочий. Единообразие статуса работы судей является основным правовым инструментом обеспечения единства судебной власти, организованной на основе полисистемности. Полномочия и срок полномочий судей не оказывают существенного влияния на их работу в качестве судьи. Все судьи рассматривают и разрешают дела по существу и представляют судебную власть. Различия в полномочиях исходят из необходимости и порождены учитыванием особенностей дела в судах с разными юрисдикциями, принадлежащим к отдельным инстанциям [6, с. 460].

Методы исследования. Статус судей Конституционного Суда выражает права и обязанности лиц, назначаемых на должность судей, а также представляет собой совокупность правовых принципов, выражающих взаимоотношения судей, общества и государства. В тоже время правовой статус судей также включает гарантии, обеспечивающие реализацию их прав и обязанностей. Статус судей и их гарантии определяет правовое положение судей.

Статус судей Конституционного Суда в зарубежных странах с точки зрения нормативного регулирования делится на две категории:

- конституционно-правовой статус;

- закреплённый в законах и других нормативно-правовых актах статус.

Кроме того, могут различаться статус судьи Конституционного Суда, пребывающего в должности, и статус судьи Конституционного Суда в отставке.

Вопрос о сроке полномочий судей Конституционного Суда в зарубежных странах разрешается различным образом:

- законом не устанавливается какое-либо ограничение на срок пребывания судьи в должности;

- устанавливается только срок пребывания судьи в должности;

- устанавливается только верхний возрастной предел пребывания судьи в должности;

- устанавливается как продолжительность срока пребывания судьи в должности, так и верхний возрастной предел пребывания судьи в должности.

Судья Конституционного Суда в Германии назначается на срок 12 лет, в Италии 9 лет, в Югославии - 5 лет и т.д. Верхний возрастной предел пребывания судьи в должности в Австрии составляет 70 лет, в Германии - 68 лет, а в Турции - 65 лет [1].

Судья Конституционного Суда, как правило, считается приступившим к выполнению своих обязанностей с момента принесения присяги.

В некоторых зарубежных странах одна треть состава Конституционного Суда периодически обновляется в порядке ротации. Например, в рамках девятилетнего течения срока полномочий в Испании одна треть судей Конституционного Суда обновляется каждые три года. 
Избрание судей Конституционного Суда Российской Федерации на второй срок полномочий не допускается.

Центральным элементом правового статуса судей Конституционного Суда являются, конечно же, права и обязанности судей Конституционного Суда. На основании анализа законодательства зарубежных стран права судей Конституционного Суда можно классифицировать следующим образом:

- участвовать во всех заседаниях Конституционного Суда с правом решающего голоса;

- требовать созыва заседания Конституционного Суда, выдвигать вопросы для рассмотрения Конституционным Судом, высказывать свое заключение по обсуждаемым вопросам;

- иные права, предусмотренные Конституцией и законами.

К основным же обязанностям судей Конституционного Суда можно отнести следующие:

- добросовестно и беспристрастно исполнять возложенные на них полномочия для разрешения дела;

- в процессе рассмотрения дела участвовать во всех заседаниях и голосованиях Конституционного Суда;

- до принятия решения по относящимся к полномочиям Конституционного Суда вопросам, изучаемых или принятых для рассмотрения Конституционным Судом, не давать разъяснений государственным органам, должностным лицам и гражданам, официальным образом не выражать свою позицию.

Фактически в соответствии с конституционным законодательством всех зарубежных стран судьи Конституционного Суда независимы в осуществлении своих полномочий и при рассмотрении дел руководствуются конституцией и законами. Независимость судей Конституционного Суда обеспечивается нижеследующим:

- несменямость судей Конституционного Суда;

- прекращение полномочий судей Конституционного Суда только на основаниях и в порядке, установленным законом;

- неприкосновенность судей Конституционного Суда;

- равноправие судей Конституционного Суда;

- недопустимость в любой форме вмешательства в профессиональную деятельность судей Конституционного Суда;

- предусмотрение материальных, социальных и иных гарантий для судей Конституционного Суда;

- гарантии безопасности [6].

Судьи Конституционного Суда обладают неприкосновенностью. Они за высказанные мнения в ходе рассмотрения дела Конституционным Судом, за решения, принятые Конституционным Судом, ни в коем случае не могут быть привлечены к юридической ответственности, в том числе и после истечения срока полномочий.

Судьи Конституционного Суда, как правило, пользуются иммунитетом такого же уровня, что и депутаты парламента.

Полномочия судей Конституционного Суда могут быть приостановлены в следующих случаях:

- арест судей;

- привлечение судей к уголовной ответственности; 
- неспособность судьи временно исполнять свои обязанности по состоянию здоровья;

- в иных случаях, предусмотренных конституцией и законами.

Следует отметить, что судья Конституционного Суда, полномочия которого приостановлены в установленном законодательством порядке, не может присутствовать на заседаниях Конституционного Суда, а также выполнять другие официальные действия в качестве судьи Конституционного Суда [4].

Изложения основного материла исследования. При устранении оснований для приостановления полномочий судьи Конституционного Суда его полномочия возобновляются. Приостановление полномочий судьи Конституционного Суда не влечет за собой прекращение материального обеспечения этого судьи и не лишает его иных гарантий, установленных конституцией и законами [4].

В мировой практике прекращение полномочий судей Конституционного Суда в основном происходит в следующих случаях:

- при утрате судьёй гражданства этой страны;

- при нарушении порядка назначения судьи на должность;

- при истечении срока полномочий судьи или достижении предельного (крайнего) возраста, установленного для пребывания в судейской должности;

- при уходе в отставку;

- при вынесении вступившего в силу обвинительного приговора в отношении судьи;

- при допущении судьёй действий, несовместимых с его должностью;

- при допущении судьёй действий, порочащих его честь и достоинство;

- при невозможности исполнения судейских обязанностей судьёй по состоянию здоровья и другим уважительным причинам в течение длительного времени;

- при нарушении судейской присяги;

- при признании судьи недееспособным по вступившему в законную силу решению суда;

- при признании судьи пропавшим без вести по вступившему в законную силу решению суда;

- в случае смерти судьи;

- в других случаях, установленных законом [3].

Судья Конституционного Суда может в любое время в добровольном порядке уйти в отставку. Это выступает одной из важнейших гарантий его независимости. Отставка также может быть вызвана обстоятельствами, не зависящими от судьи. Примером таких случаев может быть следующее:

- истечение срока полномочий;

- достижение пенсионного возраста;

- объявление судьи недееспособным и т.п.

Наряду с материальными и социальными гарантиями, предусмотренными для судей в отставке, национальным законодательством им могут быть также предоставлены другие льготы и привилегии. В Испании Председатель Конституционного Суда, заместитель Председателя и завершившие свой срок полномочий судьи Конституционного Суда на основании решения Пленума Суда обладают следующими возможностями:

- принимать особое участие во время проведения связанных с судебными вопросами торжественных мероприятий и встреч в Конституционном Суде; 
- свободным образом посещать Конституционный Суд и пользоваться оборудованием и услугами Суда;

- получать издания Конституционного Суда.

Конституция и законы не в состоянии регулировать все аспекты статуса судей Конституционного Суда. Существуют такие аспекты деятельности судей Конституционного Суда, которые требуют регулирования больше морально-этическими нормами. Этические нормы поведения судей Конституционного Суда не обобщены, и, как правило, эти вопросы решаются в конкретной ситуации в рамках индивидуальных отношений.

К сфере этического регулирования может быть отнесена и внутренняя иерархия Конституционного Суда (в особенности при проведении публичных мероприятий, не связанных с конституционным судопроизводством в Конституционном Суде). Например, в Конституционном Суде Испании с точки зрения внутренней иерархии Председатель занимает высшую позицию. После него размещаются заместитель Председателя и судьи в порядке уменьшения стажа работы в судейской должности, а при одинаковом стаже работы - в порядке уменьшения возраста судей [3].

Как правило, судебная этика исключает высказывание мнений или заключений критического характера по поводу неправильности, необоснованности и т.п. решений Конституционного Суда. Судья в особом мнении обладает правом выражать свою особую позицию, отличающуюся от позиции большинства. Однако особое мнение судьи Конституционного Суда не должно подрывать авторитет Конституционного Суда как коллегиального органа.

Одним из важных элементов статуса судей Конституционного Суда в зарубежных странах выступает вопрос наличия профессий и видов деятельности, которые не совмещаются с должностью судьи Конституционного Суда. В зарубежных странах существуют прямые запреты для судей Конституционного Суда [1]. Как правило, конституцией и законами закрепляются следующие виды деятельности, не совмещающиеся с должностью судьи Конституционного Суда:

- деятельность депутата парламента и других представительных органов (Италия, Испания, Австрия и др.);

- деятельность члена правительства (ФРГ и др.);

- работа в органах юстиции;

- административные государственные должности;

- торговая, производственная и иная коммерческая деятельность;

- выполение управленческих, ревизионных функций в компаниях;

- партийная, политическая деятельность;

- занятие руководящих должностей в профсоюзах, фондах и тому подобных организациях [1].

Законодательство большинства государств позволяет судьям Конституционного Суда заниматься научными, художественными и иными творческими видами деятельности.

Права и обязанности судей Конституционного Суда Азербайджанской Республики регулируются статьями 17 и 18 Закона Азербайджанской Республики «О Конституционном Суде» [9].

Согласно статье 17 Закона «О Конституционном Суде», судьи Конституционного Суда имеют следующие права: 
1) участвовать в заседаниях Конституционного Суда, высказывать свои мнения о проведении заседания;

2) участвовать в решении вопросов, отнесённых к полномочиям Конституционного Суда;

3) при рассмотрении вопросов в Конституционном Суде задавать вопросы судье-докладчику, участвующим в деле сторонам, заинтересованным субъектам, свидетелям и экспертам;

4) запрашивать любые документы и другую информацию у законодательных, исполнительных и судебных органов, органов местного самоуправления, а также у физических и юридических лиц в связи с вопросом, готовящимся к рассмотрению в Конституционном Суде, кроме того, заслушивать объяснения должностных лиц по этому вопросу;

5) знакомиться с ходатайствами и материалами, представленными на заседание Конституционного Суда;

6) в совещательной комнате судей высказывать мнение относительно подлежащего принятию решения Конституционного Суда, голосовать за решение или против него;

7) оставаться при особом мнении в случае несогласия с описательно-мотивировочной или резолютивной частью решения Конституционного Суда;

8) требовать проведения заседания Конституционного Суда в сроки, предусмотренные законодательством Азербайджанской Республики;

9) осуществлять иные права, предусмотренные настоящим Законом [9].

Выводы. В соответствии со статьей 18 вышеупомянутого Закона судьи Конституционного Суда в своей деятельности должны руководствоваться Конституцией Азербайджанской Республики и настоящим Законом, на основе права и справедливости беспристрастно относиться к делам при рассмотрении вопросов в Конституционном Суде, не пропускать заседаний Конституционного Суда без уважительной причины, принимать участие в голосовании по вопросам, рассматриваемым в Конституционном Суде, не допускать действий и выступлений, могущих запятнать высокое звание судьи Конституционного Суда, не нарушать требований (требований к судьям Конституционного Суда), предусмотренных статьей 11.2 Закона «О Конституционном Суде», не высказывать мнения по существу рассматриваемого в Конституционном Суде вопроса до принятия решения по данному вопросу [8]. Председатель Конституционного Суда и заместитель председателя пользуются всеми правами, принадлежащими судье Конституционного Суда, и несут те же обязанности (статья 19 Закона «О Конституционном Суде») [9].

Судья Конституционного Суда не может быть привлечен к уголовной ответственности, не может быть задержан или арестован, в отношении него не могут быть применены в судебном порядке меры административного взыскания, он не может быть подвергнут обыску и приводу, личному досмотру. Судья Конституционного Суда, задержанный в качестве лица, подозреваемого в совершении преступления или административного проступка, за исключением случаев задержания судьи Конституционного Суда на месте преступления, после установления личности должен быть немедленно освобожден, о чём в Конституционный Суд, а также Генеральному прокурору Азербайджанской Республики направляется письменное уведомление. 


\section{Jumepamypa}

1. Гулиев А.И. Юридическая энциклопедия. Баку : Ганун, 2007, 1108 с. [на азерб. языке].

2. Государственное право России : учебник / Под ред. О.Е. Кутафина. Москва : Юридическая литература, 1996, $584 \mathrm{c}$.

3. Теория государства и права : учебник для юридических факультетов и вузов / Под ред. В.М. Корельского и В.Д. Перевалова. Москва : Инфра-М, 1997, 570 с.

4. Витрук Н.В. Основы теории правового положения личности в социалистическом обществе. Москва : Юридическая литература, 1979, 223 с.

5. Правотворчество в СССР / Под ред. А.В. Мицкевича. Москва : Юридическая литература, 1974, $317 \mathrm{c}$.

6. Аскеров 3.А. Конституционное право : учебник. Баку : Издательство Бакинского университета, 2006,698 с. [на азерб. языке].

7. Конституция Азербайджанской Республики. Баку : Юридическая литература, 2016, 100 с. [на азерб. языке].

8. Абдуллаев Ф.С. Теоретические и практические проблемы конституционного производства в Азербайджанской Республике. Баку : Наука, 2009, 396 с. [на азерб. языке].

9. Закон Азербайджанской Республики «О Конституционном Суде». Баку : Ганун, 2012, 60 с. [на азерб. языке].

\section{Аннотация}

Шюкюров Н. X. Правовой статус судьи Конституционного Суда. - Статья.

В статье в сфере правового статуса судей Конституционного Суда освещается их превращение в наиболее эффективные и действенные фигуры социальной, политической и правовой жизни современной эпохи, особо отмечается их роль в устранении коллизий в законодательной системе, обеспечении стабильности и развития общества и государства. В статье также говорится, что решения, принятые судьями Конституционного Суда, имеют особое значение в развитии правовой системы, формировании нового правосознания и реализации идей конституционализма.

Ключевые слова: судья Конституционного Суда, правовой статус судьи Конституционного Суда, конституционный надзор, судебная власть, разделение власти, верховенство конституции.

\section{Анотація}

Шюкюров Н. Х. Правовий статус судді Конституційного Суду. - Стаття.

У статті в сфері правового статусу суддів Конституційного Суду висвітлюється їх перетворення на найбільш ефективні і дієві фігури соціального, політичного і правового життя сучасної епохи, особливо наголошується їх роль в усуненні колізій у законодавчій системі, забезпеченні стабільності і розвитку суспільства і держави. У статті також йдеться про те, що рішення, прийняті суддями Конституційного Суду, мають особливе значення в розвитку правової системи, формуванні нової правосвідомості і реалізації ідей конституціоналізму.

Ключові слова: суддя Конституційного Суду, правовий статус судді Конституційного Суду, конституційний нагляд, судова влада, поділ влади, верховенство конституції.

\section{Summary}

Shukurov N. H. Legal status of the judge of the Constitutional Court. - Article.

The article in the sphere of the vastness of the legal status of judges of the Constitutional Court highlights their transformation into the most effective and efficient figures of the social, political and legal life of the modern era, emphasizing their role in resolving conflicts in the legislative system, ensuring stability and development of society and the state. The article also states that the decisions adopted by the judges of the Constitutional Court are of particular importance in the development of the legal system, the formation of a new sense of justice and the implementation of the ideas of constitutionalism.

Key words: judge of the Constitutional Court, legal status of the judge of the Constitutional Court, constitutional review, judicial authority, separation of powers, supremacy of the constitution. 